\title{
Abstracts of Papers Presented at the Fourteenth Conference of European Comparative Endocrinologists
}

\author{
September 4-9, 1988, Salzburg, Austria
}

$\begin{array}{lc} & \text { Abstract } N o . \\ \text { Opening and Plenary Lectures } & 1-9 \\ \text { Brain, Hypothalamus, Pituitary I } & 57-62 \\ \text { Brain, Hypothalamus, Pituitary II } & 63-65 \\ \text { Brain, Hypothalamus, Pituitary III } & 89-94 \\ \text { Brain, Hypothalamus, Pituitary IV } & 95-97 \\ \text { Ecdysteroids I } & 25-29 \\ \text { Ecdysteroids II } & 30-34 \\ \text { Ecdysteroids III } & 35-37 \\ \text { Ecdysteroids IV } & 66-69 \\ \text { Hyperglycemic Regulation I } & 70-75 \\ \text { Hyperglycemic Regulation II } & 76-78 \\ \text { Insect/Crustacean/CNS-Corpora cardiaca I } & 102-106 \\ \text { Insect/Crustacean/CNS-Corpora cardiaca II } & 107-112 \\ \text { Interrenals, Adrenals I } & 129-131 \\ \text { Interrenals, Adrenals II } & 148-154 \\ \text { Peptide Hormones I } & 10-14 \\ \text { Peptide Hormones II } & 21-24 \\ \text { Peptide Hormones III } & 52-56 \\ \text { Peptide, Steroid Detection Methods } & 15-20 \\ \text { Pineal } & 121-128 \\ \text { Reproduction I } & 38-41 \\ \text { Reproduction II } & 42-48 \\ \text { Reproduction III } & 49-51 \\ \text { Reproduction IV } & 79-82 \\ \text { Reproduction V } & 83-86 \\ \text { Reproduction VI } & 87-88 \\ \text { Receptor Studies I } & 98-101 \\ \text { Receptor Studies II } & 140-147 \\ \text { Thyroid } & 117-120 \\ \text { Varia I } & 113-116 \\ \text { Varia II } & 132-139 \\ \text { Posters } & 159-260 \\ \text { Workshops } & 155-158\end{array}$

1. Molecular and Functional Diversity of Neuropeptides in Molluscs. J. Joosse, Biological Laboratory, Vrije Universiteit, De Boelelaan 1087, 1081 HV Amsterdam, The Netherlands.

The giant neurons in the central nervous system (CNS) of various gastropod molluscs present excellent models for a multidisciplinary approach in basic studies of neuronal functioning. In our department we use the CNS of Lymnaea stagnalis. Apart from the classical neurotransmitters in this snail the molecular diversity of 
48. Photoperiodic Effects on Vitellogenesis, Steroid Hormone Levels, and Spawning Time in the Female Sea Bass (Dicentrarchus labrax). S. Zanuy, F. Prat, N. Bromage, ${ }^{*}$ M. Carrillo, and R. Serrano, Instituto de Acuicultura de Torre de la Sal, Ribera de Cabanes, 12595 Castellón, Spain, and *Institute of Aquaculture, University of Stirling, Stirling FK94LA, Scotland.

Previously, we have shown that the timing of spawning in the sea bass, which in eastern Spain (40 $0^{\circ} \mathrm{N}$ lat) occurs in February/March under natural conditions, can be altered by photoperiodic manipulation. However, the nature of the photoperiodic cue and the stage(s) of development affected in this response remains unclear. These questions are further investigated in the present study where different groups of 20 male and female sea bass were exposed to 1 month of long days (15L:9D) in May (Group C), June (D), or July (E) in an otherwise constant short day (9L:15D) photoperiod regime. Further groups were exposed to short days throughout (Group A) and to ambient light (controls). Temperature varied between $13^{\circ} \mathrm{C}$ in winter to $25^{\circ} \mathrm{C}$ in summer and fish were fed ad libitum daily with fresh trash fish. In control fish plasma estradiol $\left(\mathrm{E}_{2}\right)$ and testosterone $(T)$ levels rose in September/October followed closely by increases in vitellogenin ( $\mathrm{Vg}$, as calcium); $\mathrm{E}_{2}$ and $\mathrm{T}$ values both fell toward basal levels by the end of spawning (March) whereas $\mathrm{Vg}$ levels were not reduced until April. Long days in May produced advancements in the timing of the seasonal changes of $E_{2}, T$, and $\mathrm{Vg}$ compared to controls. Similar but less advanced changes in these parameters were seen in Group D, followed in timing by those in Groups $\mathrm{E}$ and $\mathrm{A}$. In each case $\mathrm{Vg}$ incorporation into the cocytes began when $\mathrm{Ca}$ levels reached $14-15 \mathrm{mg} \%$. The profile of spawning was most advanced in Group $C$ followed by $D, E$, and $A$ and then the controls. Collectively, these data indicate that ovarian development in the sea bass is controlled by hormonal mechanisms whose timing can be altered by photoperiodic change. (This work was supported by an Anglo-Spanish Joint Research Programme (SPN/991/3/44) and a CAICYT Research Grant (3/83).)

49. Vitellogenesis and Steroid Levels in the Siberian Sturgeon Acipenser baeri Bred in Fish Farm. C. Pelissero, ${ }^{*}$ F. Le Menn, ${ }^{*}$ and F. Burzawa-Gerard, $\dagger$ *Lab de Biologie Marine, University de Bordeaux I, Talence, France, and †Lab de Physiologie Generale et Comparee, Museum d'Histoire Naturelle, Paris, France.

Plasmatic testosterone $(T)$, estrone $\left(E_{1}\right)$, and estradiol $\left(E_{2}\right)$ levels are determined in 4-, 5-, 6-, and 10year-old Acipenser baeri. The fish are bred in the INRA/CEMAGREF hatchery of Donzacq (France) where particular thermic and diet conditions allow high growth rate and rapid sexual development. The data obtained show that $T$ and $E_{1}$ levels evolve in relative accordance with those already measured in teleosts along their sexual development. In return, plasmatic $\mathrm{E}_{2}$ levels in males and females are never significantly different. They induce in both cases vitellogenin synthesis correlated with plasmatic alcali-labile phosphorus levels. The vitellogenin presence in females and males should be linked to an $\mathrm{E}_{2}$ diet contamination since this steroid is still present in fish flours as demonstrated by radioimmunoassays on diet extracts.

50. Plasma Cortisol Profiles of Female Rainbow Trout (Salmo gairdneri) at the End of the Reproductive Cycle:

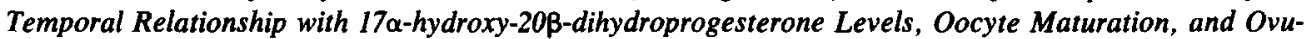
lation, Based on Daily Samplings of Individual Fish. C. BRY, Laboratoire de Génétique des Poissons, INRA, 78350 Jouy-en-Josas, France.

Two-three weeks before ovulation, dorsal aorta catheterization was performed in large female rainbow trout previously subjected to acclimation procedures (setting up of a sham catheter and practice of simulated blood collections). For each fish, isolated in a 300 liter compartment at $10^{\circ} \mathrm{C}$, active food intake was checked at $0930 \mathrm{hr}$ and $150 \mu \mathrm{l}$ of blood was sampled at $1230 \mathrm{hr}$ on a daily basis during 3-5 weeks postcatheterization. The day of ovulation was later identified with precision for each female by comparing the individual $17 \alpha$-hydroxy-20 $\beta$-dihydroprogesterone $(17 \alpha, 20 \beta-P)$ profile with a calibration curve $(17 \alpha, 20 \beta-P$ levels vs days before ovulation) previously established from similar females. Basal cortisol levels were low (1-3 $\mathrm{ng} \mathrm{ml}^{-1}$ ) until a few days before ovulation. In all studied females a marked elevation of plasma cortisol was detected within the close periovulatory period. Mean cortisol concentrations began to increase on Day 2 preovulation, i.e., after the firșt steep increase in $17 \alpha, 20 \beta-P$ recorded on Day 4 before ovulation. Peak values (23-50 $\mathrm{ng} \mathrm{ml}-1$ ) occurred between Day 2 preovulation and Day 1 postovulation, depending on the female. The average cortisol profile showed a maximum ( $24 \mathrm{ng} \mathrm{ml}^{-1}$ ) on the very day of ovulation. After ovulation, cortisol levels gradually returned to low basal values. These results show that elevated cortisol concentrations mainly occur at the end of the oocyte maturation period and at the time of ovulation in female rainbow trout. While not excluding a synergistic action of cortisol during the course of oocyte maturation, these data rather draw the attention on the possible role(s) of cortisol in the process of ovulation itself in female teleost fish. 